\title{
Proximity to major roadways is a risk factor for airway hyper-responsiveness in adults
}

\author{
Shannon Riley BSc${ }^{1}$, Julie Wallace PhD $^{2}$, Parameswaran Nair MD PhD FRCP FRCPC ${ }^{1}$
}

S Riley, J Wallace, P Nair. Proximity to major roadways is a risk factor for airway hyper-responsiveness in adults. Can Respir J 2012;19(2):89-96.

BACKGROUND: Proximity to major roads is reported to be associated with asthma and airway hyper-responsiveness in children. Similar studies using objective measurements in adults are not available in Canada.

OBJECTIVE: To test the hypothesis that adult asthmatic patients who live close to major roads and highways in an urban environment are at a risk of moderate to severe airway hyper-responsiveness.

METHODS: Airway responsiveness was determined using methacholine bronchial provocation $\left(\mathrm{PC}_{20}\right)$ tests in a cohort of 2625 patients who attended an outpatient clinic in Hamilton, Ontario. Patient addresses were geocoded in a geographic information system to determine proximity to major roads and highways. Multivariate linear and multinomial regression analyses were used to assess whether proximity to roads was a risk factor for airway hyper-responsiveness as measured by $\mathrm{PC}_{20}$ methacholine.

RESULTS: Patients who lived within $200 \mathrm{~m}$ of a major road had increased odds (OR 1.38 [95\% CI 1.04 to 1.85]) of having moderate airway hyperresponsiveness $\left(0.25 \mathrm{mg} / \mathrm{mL}<\mathrm{PC}_{20}<2.0 \mathrm{mg} / \mathrm{mL}\right)$ compared with having a normal response $\left(\mathrm{PC}_{20}>16 \mathrm{mg} / \mathrm{mL}\right)$. Spatial analysis also revealed that the majority of patients with severe airway hyper-responsiveness lived within the urban core of the city while those with moderate to mild hyper-responsiveness were also dispersed in rural areas.

CONCLUSIONS: In an adult population of patients attending an outpatient respiratory clinic in Hamilton, living close to major roadways was associated with an increased risk of moderate airway hyper-responsiveness. This correlation suggests that exposure to traffic emissions may provoke the pathology of airway hyper-responsiveness leading to variable airflow obstruction.

Key Words: Air pollution; Airway responsiveness; Asthma; Road traffic; Spatial analysis

\section{La proximité de deux grandes autoroutes est un facteur de risque d'hyperréactivité des voies aériennes chez les adultes}

HISTORIQUE : Ondéclare que la proximité des grandes routes s'associe à l'asthme et à l'hyperréactivité des voies aériennes chez les enfants. Il n'existe pas de données similaires au moyen de mesures objectives chez les adultes au Canada.

OBJECTIF : Évaluer l'hypothèse selon laquelle les patients asthmatiques symptomatiques qui vivent à proximité des grandes routes et des autoroutes en environnement urbain sont vulnérables à une hyperréactivité des voies aériennes modérée à grave.

MÉTHODOLOGIE : Les chercheurs ont déterminé la réactivité des voies aériennes à l'aide d'épreuves de provocation bronchique $\left(\mathrm{PC}_{20}\right)$ à la méthacholine dans une cohorte de 2625 patients qui fréquentaient une clinique ambulatoire de Hamilton, en Ontario. Ils ont géocodé les adresses des patients dans un système d'information géographique pour déterminer la proximité des grandes routes et des autoroutes. Ils ont utilisé des analyses linéaires multivariées et des analyses de régression multinomiale pour évaluer si la proximité aux routes constituait un facteur de risque d'hyperréactivité des voies aériennes, tel qu'il est évalué par la $\mathrm{PC}_{20}$ à la méthacholine.

RÉSULTATS : Les patients qui vivaient à moins de 200 mètres d'une grande route risquaient davantage (RRR 1,38 [95 \% IC 1,04 à 1,85]) de présenter une hyperréactivité modérée des voies aériennes $\left(0,25 \mathrm{mg} / \mathrm{mL}<\mathrm{PC}_{20}<2,0 \mathrm{mg} / \mathrm{mL}\right)$ qu'une réponse normale $\left(\mathrm{PC}_{20}>16 \mathrm{mg} / \mathrm{mL}\right)$. L'analyse spatiale a également révélé que la majorité des patients ayant une hyperréactivité des voies aériennes marquée vivaient au centre urbain de la ville, tandis que ceux ayant une hyperréactivité bénigne à moyenne étaient dispersés en région rurale. CONCLUSIONS : Dans une population adulte de patients qui fréquentent une clinique respiratoire ambulatoire de Hamilton, le fait de vivre à proximité de grandes routes s'associait à une augmentation du risque d'hyperréactivité modérée des voies aériennes. Cette corrélation laisse supposer que l'exposition aux émissions de la circulation pourrait provoquer la pathologie de l'hyperréactivité des voies aériennes qui entraîne une obstruction variable des voies aériennes.

Studies investigating the prevalence or worsening of asthma often lack an objective measurement of airway inflammation or airway hyper-responsiveness (AHR). Respiratory symptoms and the presence of physician-diagnosed asthma were commonly self-reported by study participants using questionnaires. The major limitation of this method of assessment is that it relies solely on the participant's perception of symptoms and disease severity. Furthermore, the method by which a physician diagnosed a participant's asthma is often not reported or standardized among subjects. To understand true changes in the airway that may be induced by traffic pollution, studies that focus on objective measurements of airway pathophysiology are necessary.

Our study investigated the relationship between AHR and residence proximity to major highways and arterial roads for adult subjects living in the Hamilton Census Metropolitan Area (CMA), Ontario. The study population consisted of adult patients (18 to 88 years of age) who attended a respiratory outpatient clinic. The majority of these patients were predisposed to respiratory illness and, hence, we surmise that there could be an increased risk of AHR for patients who live near major roads or highways. decreased pulmonary function, particularly in women $(16,17)$ and adults with physician-diagnosed asthma (18-20).

${ }^{1}$ Firestone Institute for Respiratory Health, St Joseph's Healthcare and Department of Medicine, McMaster University; ${ }^{2}$ The Hamilton Institute for

Humanity and the Environment, Hamilton, Ontario

Correspondence: Dr Julie Wallace, The Hamilton Institute for Humanity and the Environment, 27-7 Davidson Boulevard, Hamilton,

Ontario L9H 6Y7. E-mail julie@thehamiltoninstitute.org 


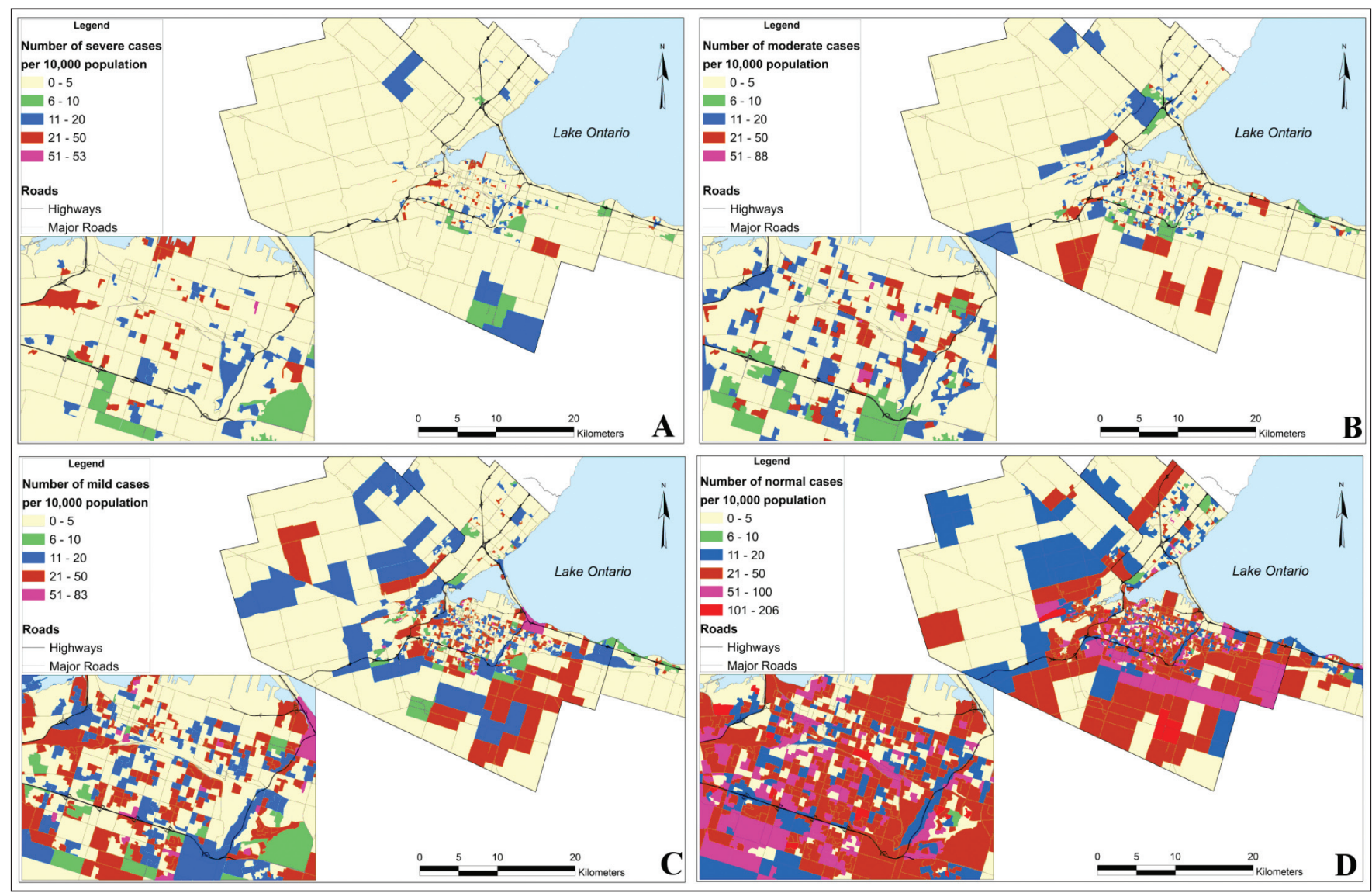

Figure 1) Maps showing the number of study cases of hyper-responsiveness per 10,000 persons in the study area. A Severe. B Moderate. C Mild. D Normal

\section{Study design}

The study was a retrospective analysis of a computerized database of 2143 patients who reside in the study area. The patients were referred to the outpatient clinic at the Firestone Institute of Respiratory Health in Hamilton (Ontario) between January 2007 and June 2010 for evaluation of respiratory symptoms suggestive of asthma. Given the nature of this patient population, a significant number are more likely to have pre-existing airway disease when compared with the general population. Those with pre-existing airway disease may be more susceptible to the respiratory effects of motor vehicle pollution (18). Because some patients visited the clinic on multiple occasions, only data from first visits were used in the present study. Airway responsiveness was measured using the methacholine provocation method $(21,22)$ to determine the provocative concentration of methacholine $\left(\mathrm{PC}_{20}\right)$ that led to a $20 \%$ fall in forced expiratory volume $\left(\mathrm{FEV}_{1}\right)$, using American Thoracic Society guidelines (23). Spirometry was performed according to American Thoracic Society standards (24). Patient's medication of inhaled corticosteroids (ICS) and long (LABA)- and short-acting beta ${ }_{2}$-agonists (SABA) being used at the time of the methacholine challenge were recorded. In general, ICS was not withheld for the test. LABA was held for $24 \mathrm{~h}$ and SABA for $6 \mathrm{~h}$ before the test. ICS doses are reported as the standard dose of fluticasone equivalent. The extrapolated $\mathrm{PC}_{20}$ data for each patient, together with the patient's date of visit, address, age, sex, baseline spirometry and respiratory medications, were extracted from a computerized database.

\section{Study area}

The Hamilton CMA is located at the western tip of Lake Ontario, (Figure 1) and has a population of 700,000 . Hamilton is a mid-size industrial city, with the major industrial sector located on the shores of
Lake Ontario. Provincial highways, which carry several tens of thousands of vehicles daily, are routed through the city and major arterial roads carry up to 20,000 vehicles daily. Air pollution in Hamilton is high compared with less commercially and industrially active Canadian cities. For example, the mean concentrations of oxides of nitrogen and fine particulate matter in Hamilton for 2008 were $21 \mathrm{ppb}$ and $8.3 \mu \mathrm{g} / \mathrm{m}^{3}$, respectively, compared with $14 \mathrm{ppb}$ and $5.3 \mu \mathrm{g} / \mathrm{m}^{3}$, respectively, in the nation's captial of Ottawa (25).

\section{Geographical analysis}

Patients' home addresses were mapped to the local street network so that proximity to highways and major roads could be determined. The addresses were geocoded with the Geographic Information System software package ArcGIS 9.3 (ESRI, USA). Major roads and highways were defined using the road classifications of expressways, rural highways and arterial roads. For the present study, expressways were termed 'highways', and rural highways and arterial roads were grouped together as 'major roads' because they carry similar volumes of traffic. Distance from each patient's home address to the nearest roadway, whether a highway or major road, was determined using Geographic Information System software. This provided a continuous distance variable. The distances were further classified into discrete buffer zones from each road, beginning with $25 \mathrm{~m}$ from each road and increasing to $400 \mathrm{~m}$. Distances greater than $400 \mathrm{~m}$ were grouped together as $>400 \mathrm{~m}$. The discrete buffer zones were used as binary variables in the statistical analyses, indicating whether the patient lived inside or outside that zone. A $500 \mathrm{~m}$ buffer zone was also created around the major industrial zone to control for the effect of industrial pollution on persons who lived within this zone.

The buffer zone radii were similar to the $20 \mathrm{~m}$ to $50 \mathrm{~m}$ buffer zones used in previous studies that examined the association between living in proximity to major roadways and respiratory symptoms such as chronic 


\begin{tabular}{|c|c|c|c|c|c|c|c|c|}
\hline & \multirow[b]{2}{*}{ n (\% female) } & \multirow[b]{2}{*}{ Age $^{*}$, years } & \multicolumn{2}{|c|}{ Distance $^{\star}, \mathrm{m}$} & \multirow[b]{2}{*}{$\begin{array}{c}\mathrm{FEV}_{1} \% \\
\text { predicted (\%) }\end{array}$} & \multirow[b]{2}{*}{$\mathrm{ICS}^{\dagger \neq}, \mu \mathrm{g}$} & \multirow[b]{2}{*}{$\mathrm{LABA}^{\ddagger}, \mu \mathrm{g}$} & \multirow[b]{2}{*}{$\mathrm{PC}_{20} \S, \mathrm{mg} / \mathrm{mL}$} \\
\hline & & & $\begin{array}{c}\text { From major } \\
\text { roads }\end{array}$ & $\begin{array}{c}\text { From } \\
\text { highways }\end{array}$ & & & & \\
\hline All & $2145(64)$ & $46(23)$ & $168(229)$ & 265 (239) & $95.8(20.1)$ & $0(0,2400)$ & $0(0,200)$ & $2.95(5.51)$ \\
\hline Severe $(<0.25)$ & $93(72)$ & $41(29)$ & $189(203)$ & $188(159)$ & $84.1(18.6)$ & $0(800,1600)$ & $0(0,200)$ & $0.04(0.11)$ \\
\hline Moderate $(0.25-2.0)$ & $231(73)$ & $46(24)$ & $140(210)$ & $229(397)$ & $84.6(17.3)$ & $0(500,1600)$ & $0(0,100)$ & $1.05(0.91)$ \\
\hline Mild (2.1-16.0) & $458(69)$ & $46(23)$ & 169 (229) & 279 (187) & $92.8(17.6)$ & $0(250,1600)$ & $0(0,100)$ & $5.60(5.50)$ \\
\hline
\end{tabular}

${ }^{*}$ Data presented as as median (interquartile range [IQR]); ${ }^{\dagger}$ Fluticasone equivalent; ${ }^{\ddagger}$ Dosage data presented as median (IQR, full range); ${ }^{\S}$ Data presented as median (IQR) for $P C_{20}<16 \mathrm{mg} / \mathrm{mL}$. FEV $V_{1}$ Forced expiratory volume in $1 \mathrm{~s}$; ICS Inhaled corticosteroid; LABA Long-acting beta ${ }_{2}$-agonist; $P C_{20} P$ Provocative concentration of methacholine causing a 20\% decline in FEV

TABLE 2

Patients in three classes of airway hyper-responsiveness and the normal group living within discrete distance zones from highways and major roads

\begin{tabular}{|c|c|c|c|c|c|c|c|c|c|c|}
\hline \multirow[b]{2}{*}{ Distance, m } & \multicolumn{5}{|c|}{ Highways } & \multicolumn{5}{|c|}{ Major roads } \\
\hline & Severe & Moderate & Mild & Normal & Total & Severe & Moderate & Mild & Normal & Total \\
\hline $0-49$ & 0 & 0 & 1 & 1 & 2 & 16 & 47 & 78 & 271 & 412 \\
\hline 50-99 & 0 & 1 & 4 & 17 & 22 & 6 & 34 & 50 & 142 & 232 \\
\hline 100-149 & 4 & 4 & 5 & 20 & 33 & 11 & 30 & 58 & 148 & 247 \\
\hline 150-199 & 1 & 1 & 2 & 19 & 23 & 11 & 31 & 50 & 137 & 229 \\
\hline 200-249 & 0 & 4 & 5 & 22 & 31 & 11 & 13 & 41 & 120 & 185 \\
\hline 250-299 & 3 & 0 & 8 & 18 & 29 & 9 & 12 & 33 & 87 & 141 \\
\hline $300-349$ & 0 & 1 & 8 & 17 & 26 & 4 & 15 & 15 & 64 & 98 \\
\hline $350-400$ & 0 & 0 & 3 & 7 & 10 & 3 & 8 & 23 & 49 & 83 \\
\hline
\end{tabular}

Data presented as $n$

phlegm and wheeze $(9,13,14,26)$. A study by Zhu et al (27) showed that the concentration of ultrafine particulate matter from traffic can be 25 times higher than background levels near major highways. Concentrations of traffic pollutants such as carbon monoxide, black carbon and particulate matter were measured at $30 \mathrm{~m}, 60 \mathrm{~m}, 90 \mathrm{~m}, 150 \mathrm{~m}$ and $300 \mathrm{~m}$ downwind from a major interstate highway. Particulate matter concentrations were found to decrease exponentially with increasing distance from the roadway, reaching background concentrations at $300 \mathrm{~m}$ downwind. Therefore, discrete buffer zones of $25 \mathrm{~m}$ were used in the present study to determine the distance at which traffic pollution may exert a significant effect on AHR.

\section{Statistical analysis}

All analyses were adjusted for patients' age, sex, $\mathrm{FEV}_{1} \%$ predicted, average ambient temperature and relative humidity on the day of the patient's visit, proximity to industry, and dummy variables to indicate whether the patient was taking ICS or LABA. Meteorological data were obtained from the Environment Canada meteorology station at the Hamilton International Airport. Tests of spatial autocorrelation were performed using Geoda version 9.8.10 (Arizona State University, 2009) to determine whether there were underlying spatial patterns in the residuals of ordinary least squares regression analyses (28). Subsequent multivariate linear and multinomial regression analyses were performed with SPSS version 18 (IBM Corporation, USA). Regression analyses investigated whether there was a statistically significant relationship between the $\mathrm{PC}_{20}$ measure of $\mathrm{AHR}$ and proximity to highways and major roads. Multivariate linear regression analyses were used to determine the relationship between outcome of $\mathrm{PC}_{20}$ testing and distance from roads both as continuous variables with log transformations to normalize their frequency distributions. Multinomial regression analyses were also performed, with $\mathrm{PC}_{20}$ concentrations classified into four groups: class 1 - severe $(<0.25 \mathrm{mg} / \mathrm{mL})$, class 2 - moderate $(0.25 \mathrm{mg} / \mathrm{mL}$ to $2.0 \mathrm{mg} / \mathrm{mL})$, class 3 - mild $(2.1 \mathrm{mg} / \mathrm{mL}$ to $16.0 \mathrm{mg} / \mathrm{mL})$ and class 4 normal $(>16.0 \mathrm{mg} / \mathrm{mL})$. Class 4 was used as the reference group.

\section{Descriptive statistics}

\section{RESULTS}

Table 1 summarizes the patient characteristics for the study group overall and for each classification of $\mathrm{PC}_{20}$. Patients' ages ranged from 18 to 88 years, with a median of 46 years and an interquartile range of 23 years. The majority were women (64\%). A total of 699 patients (33\%) were taking ICS at doses up to $2400 \mu \mathrm{g}$ and $396(18 \%)$ were taking LABA at doses up to $200 \mu \mathrm{g}$. The vast majority of patients displayed normal $\mathrm{PC}_{20}$ responses $(63.5 \%)$, with $4.3 \%$ severe, $10.8 \%$ moderate and $21.4 \%$ mild cases. The median age of patients in the severe group (41 years) was appreciably lower than those in the normal group (48 years). Median distance from roads indicates that patients with severe AHR lived closest to highways $(188 \mathrm{~m})$, while patients with moderate AHR lived closest to major roads $(140 \mathrm{~m})$. Table 2 presents the number of patients who lived in discrete buffer zones from major roads and highways, and shows that the greatest number of all groups, including the normal group, lived close to major roads. This was less well defined for highways because few people live very close to highways.

The spatial distribution of the number of cases in each $\mathrm{PC}_{20}$ group was mapped using the census dissemination area in which they were located (Figure 1). A dissemination area is the smallest geographical census unit used by Statistics Canada and is defined to include 400 to 700 persons. For comparison, the distribution was mapped as the number of cases per 10,000 persons. Figure $1 \mathrm{~A}$ shows that the severe group was located almost exclusively within the built-up urban area with a dense network of roads. Of these, many cases were close to highways. Figure $1 \mathrm{~B}$ shows the moderate cases who are more widely distributed in the urban centre but are also found in the peripheral rural areas. Mild cases (Figure 1C) are more widespread, with high concentrations in the urban areas but also distributed in rural areas. Figure 1D shows the normal cases who were located throughout the urban centre, and more in the southern rural areas than in the northern rural areas. 
TABLE 3

Results of multivariate linear regression analyses showing the relationship between the dependent variable $\left(\mathrm{PC}_{20}\right)$ and the independent variables including distance from major roads and highways

\begin{tabular}{|c|c|c|c|c|c|c|}
\hline \multirow[b]{2}{*}{ Independent variables } & \multicolumn{3}{|c|}{ Highways $(n=70)$} & \multicolumn{3}{|c|}{ Major roads $(n=712)$} \\
\hline & B & $\mathbf{P}$ & $95 \% \mathrm{Cl}$ & B & $\mathbf{P}$ & $95 \% \mathrm{Cl}$ \\
\hline \multicolumn{7}{|l|}{ Unadjusted model } \\
\hline Distance from highways and major roads & 0.021 & 0.942 & -0.560 to 0.603 & -0.003 & 0.949 & -0.085 to 0.079 \\
\hline \multicolumn{7}{|l|}{ Adjusted model } \\
\hline Age, years & -0.01 & 0.208 & -0.022 to 0.005 & 0.006 & 0.000 & 0.003 to 0.009 \\
\hline $\mathrm{FEV}_{1}, \%$ predicted & 0.012 & 0.136 & -0.004 to 0.027 & 0.016 & 0.000 & 0.012 to 0.020 \\
\hline Female & -0.293 & 0.168 & -0.713 to 0.127 & -0.115 & 0.058 & -0.234 to 0.004 \\
\hline Taking inhaled corticosteroids* & 0.057 & 0.815 & -0.427 to 0.540 & -0.223 & 0.002 & -0.366 to -0.080 \\
\hline Taking long-acting beta ${ }_{2}$-agonists & -0.274 & 0.299 & -0.797 to 0.249 & 0.087 & 0.290 & -0.074 to 0.249 \\
\hline Temperature, ${ }^{\circ} \mathrm{C}$ & 0.010 & 0.329 & -0.010 to 0.030 & 0.002 & 0.513 & -0.003 to 0.007 \\
\hline Relative humidity, \% & 0.010 & 0.272 & -0.008 to 0.027 & -0.003 & 0.160 & -0.008 to 0.001 \\
\hline Living within $500 \mathrm{~m}$ of industry & 0.587 & 0.112 & -0.140 to 1.313 & 0.078 & 0.368 & -0.092 to 0.248 \\
\hline Distance from highways and major roads & 0.187 & 0.542 & -0.425 to 0.800 & 0.005 & 0.899 & -0.074 to 0.084 \\
\hline
\end{tabular}

${ }^{*}$ Fluticasone equivalent. FEV ${ }_{1}$ Forced expiratory volume in $1 \mathrm{~s} ; P_{20}$ Provocative concentration of methacholine causing a $20 \%$ decline in FEV 1

\section{TABLE 4}

Multinomial regression analysis for patients who live closer to highways than major roads, with outcomes of three classes of airway hyper-responsiveness with reference to the normal group $\left(\mathrm{PC}_{20}>16 \mathrm{mg} / \mathrm{mL}[\mathrm{n}=160]\right)$

\begin{tabular}{|c|c|c|c|}
\hline $\begin{array}{l}\mathrm{PC}_{20} \text { class } \\
\text { Independent variables }\end{array}$ & B & $\mathbf{P}$ & OR $(95 \% \mathrm{Cl})$ \\
\hline \multicolumn{4}{|l|}{ Severe $(n=9)$} \\
\hline Age, years & 0.02 & 0.396 & $1.02(0.97-1.08)$ \\
\hline Ambient temperature, ${ }^{\circ} \mathrm{C}$ & 0.01 & 0.784 & $1.01(0.94-1.09)$ \\
\hline Relative humidity, \% & 0.04 & 0.356 & $1.04(0.96-1.13)$ \\
\hline $\mathrm{FEV}_{1}, \%$ predicted & -0.08 & 0.010 & $0.92(0.87-0.98)$ \\
\hline Taking ICS* & 1.19 & 0.300 & $3.27(0.35-30.86)$ \\
\hline Taking LABA & 1.13 & 0.323 & $3.10(0.33-29.24)$ \\
\hline Female & 2.33 & 0.045 & $10.32(1.05-101.17)$ \\
\hline Within $300 \mathrm{~m}$ of highway & 1.78 & 0.125 & $5.92(0.61-57.35)$ \\
\hline \multicolumn{4}{|l|}{ Moderate $(n=17)$} \\
\hline Age, years & -0.01 & 0.637 & 0.99 (0.95-1.03) \\
\hline Ambient temperature, ${ }^{\circ} \mathrm{C}$ & 0.01 & 0.739 & 1.01 (0.96-1.07) \\
\hline Relative humidity, \% & -0.02 & 0.487 & $0.98(0.94-1.03)$ \\
\hline $\mathrm{FEV}_{1}, \%$ predicted & -0.10 & $<0.010$ & $0.90(0.86-0.95)$ \\
\hline Taking ICS* & 0.06 & 0.939 & $1.06(0.21-5.30)$ \\
\hline Taking LABA & 1.16 & 0.186 & $3.19(0.57-17.82)$ \\
\hline Female & 1.21 & 0.057 & $3.36(0.97-11.72)$ \\
\hline Within $300 \mathrm{~m}$ of highway & -0.22 & 0.701 & $0.80(0.26-2.49)$ \\
\hline \multicolumn{4}{|l|}{ Mild $(n=44)$} \\
\hline Age, years & -0.01 & 0.257 & $0.99(0.96-1.01)$ \\
\hline Ambient temperature, ${ }^{\circ} \mathrm{C}$ & 0.03 & 0.100 & $1.03(0.99-1.08)$ \\
\hline Relative humidity, \% & 0.06 & 0.002 & 1.07 (1.02-1.11) \\
\hline $\mathrm{FEV}_{1}, \%$ predicted & -0.03 & 0.041 & $0.97(0.94-1.00)$ \\
\hline Taking ICS* & 1.36 & 0.010 & 3.88 (1.39-10.87) \\
\hline Taking LABA & -0.28 & 0.658 & $0.76(0.22-2.62)$ \\
\hline Female & 0.12 & 0.775 & $1.12(0.51-2.49)$ \\
\hline Within $300 \mathrm{~m}$ of highway & -0.21 & 0.591 & $0.81(0.38-1.74)$ \\
\hline
\end{tabular}

*Fluticasone equivalent. FEV 1 Forced expiratory volume in $1 \mathrm{~s}$; ICS Inhaled corticosteroid; LABA Long-acting beta ${ }_{2}$-agonist; $P C_{20}$ Provocative concentration of methacholine causing a $20 \%$ decline in FEV

Spatial autocorrelation

Ordinary least square regression analyses were performed with the outcome of $\mathrm{PC}_{20}$, controlling for the variables indicated. Moran's I measure of global spatial autocorrelation $(-0.002)$ was not statistically significant, and subsequent spatial autoregressive models indicated that the spatial lag and spatial error variables were also not significant in their respective models. Residuals were randomly distributed with zero slope and normal distributions. Therefore, ordinary multivariate regression analyses were performed.

Regression analysis

Linear multivariate regression with $\log$ transformed $\mathrm{PC}_{20}$ was performed for $\mathrm{PC}_{20}<16 \mathrm{mg} / \mathrm{mL}$. The normal group was excluded from these analyses because the very high proportion of these cases $(63.5 \%)$ created an extreme skew that could not be adjusted with any transformation. Distance from roadways was used as a continuous variable. Separate analyses were performed for subjects that were closest to highways $(n=70)$ and subjects that were closer to major roads than highways $(n=712)$. Distance from highways was not a significant predictor of $\mathrm{PC}_{20}$, although the positive regression coefficient suggests an increase in $\mathrm{PC}_{20}$ with increasing distance (Table 3). No other variable proved to be significant for this group. The result for the unadjusted model was similar (Table 3). For the group living closest to major roads, the results identified a similarly nonsignificant increase in $\mathrm{PC}_{20}$ with increasing distance from major roads (Table 3). Age and $\mathrm{FEV}_{1} \%$ predicted were significant at the $95 \%$ level, with increases in $\mathrm{PC}_{20}$ with age $\left(\mathrm{P}<0.005\right.$ [95\% CI 0.003 to 0.009]) and with $\mathrm{FEV}_{1} \%$ predicted $(\mathrm{P}<0.005$ [95\% CI 0.012 to 0.020$])$. In the unadjusted model, distance from roads was also not significant ( $\mathrm{P}=0.949$ [95\% CI -0.085 to 0.079$]$ ), but confounders did improve the model (Table 3). Overall, the positive regression coefficients in the adjusted model may suggest a possible increase in $\mathrm{PC}_{20}$ with increasing distance from highways and major roads. However, there was no statistical significance and, thus, no definitive relationship. Because the normal group was not included in these analyses, multinomial regression analyses were performed.

Results of the multinomial regression better defined the associations because all classes of $\mathrm{PC}_{20}$ were used. Analyses were also performed separately for subjects living closer to highways and those closer to major roads. Discrete $25 \mathrm{~m}$ distance buffers were used to designate distance from roadways, beginning at $25 \mathrm{~m}$ and increasing incrementally by $25 \mathrm{~m}$, up to $400 \mathrm{~m}$. Binary variables were used to indicate whether the patient resided within or outside a buffer zone. The advantage of using a discrete distance and categorical variables in this manner is that it becomes possible to identify the distance at which AHR is significantly impacted by the road traffic. All distance increments were tested, but only the most significant results are presented.

Results for proximity to highways are summarized in Table 4. Sample sizes were small and, hence, the results are not reliable. However, the most significant result (Table 4) suggests a nonsignificant increase in the odds of being in the severe group compared with the normal group for 


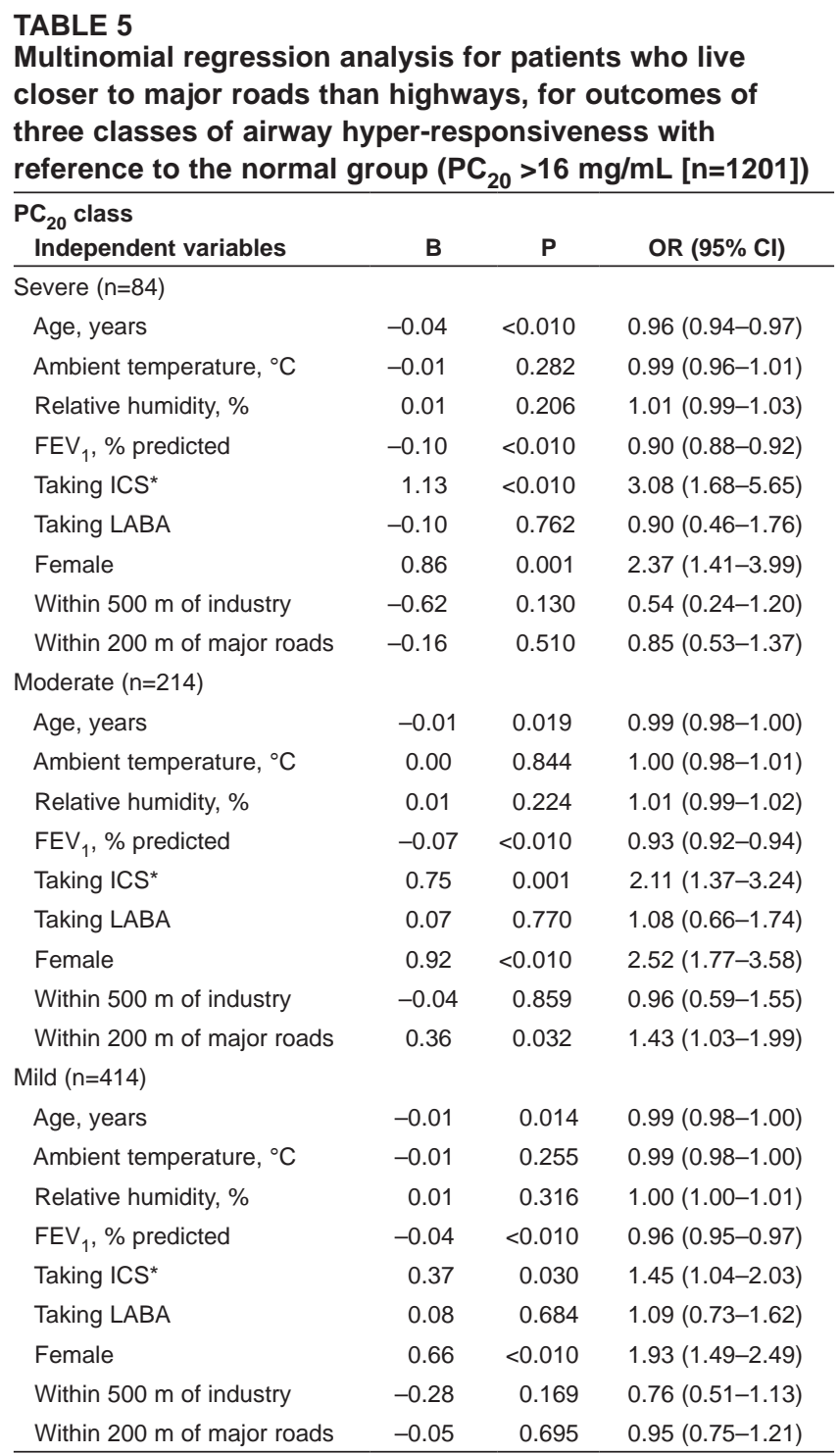

*Fluticasone equivalent. FEV ${ }_{1}$ Forced expiratory volume in $1 \mathrm{~s}$; ICS Inhaled corticosteroid; LABA Long-acting beta ${ }_{2}$ - agonist; $P C_{20}$ Provocative concentration of methacholine causing a $20 \%$ decline in FEV 1

those who lived within $300 \mathrm{~m}$ of a highway (OR 5.92 [95\% CI 0.61 to 57.35]). While the number of individuals in the severe group $(n=9)$ was clearly insufficient, the results were generally consistent with the data presented in Table 1, which suggests that subjects with the most severe disease live nearest to highways. Unadjusted results for the $300 \mathrm{~m}$ zone were similar (OR 5.2 [95\% CI 0.63 to 42.5]). There was an insufficient number of patients living closer than $300 \mathrm{~m}$ to the highways for analysis.

Table 5 summarizes the results of multinomial regression analyses for major roads. The results suggest that the odds of being in the moderate group rather than the normal group increased by a factor of 1.43 for patients living within $200 \mathrm{~m}$ of a major road (OR 1.43 [95\% CI 1.03 to 1.99). This result is statistically significant and is consistent with the descriptive data in Table 1, which indicate that persons with moderate AHR lived closest to major roads. Analyses for distance buffers of $150 \mathrm{~m}, 175 \mathrm{~m}$ and $225 \mathrm{~m}$ were not statistically significant at the $95 \%$ level, but were at the $90 \%$ level. The ORs and CIs for distances of $100 \mathrm{~m}$ to $400 \mathrm{~m}$ area displayed in Figure 2 for a graphical comparison. While distances closer than $200 \mathrm{~m}$ were not statistically significant at the 95\% level, there is an indication of the increased odds of patients being in the moderate rather than the normal group at these closer distances. Unadjusted results similarly show that moderate AHR is associated with

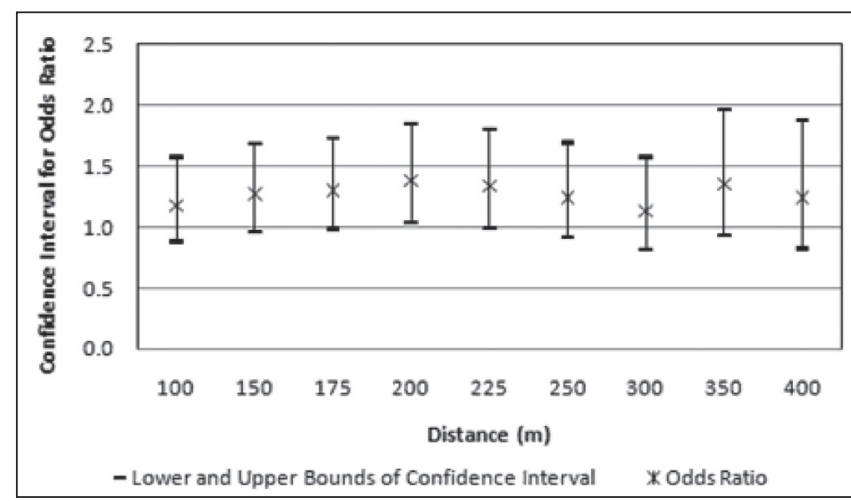

Figure 2) Confidence intervals and odds ratios for outcomes of moderate hyper-responsiveness (class 2) compared with normal responses (class 4), at multiple distances from major roads

proximity to major roads, but places greater significance at $175 \mathrm{~m}$ (OR 1.34 [95\% CI 1.00 to 1.80]), and statistically significant at $200 \mathrm{~m}$ (OR 1.42 [95\% CI 1.05 to 1.93$]$ ) indicating that the independent variables do modify the impact of traffic.

Of the other explanatory variables, age was statistically significant, and a one year increase in age decreased the odds of being in the severe group by $4 \%$, in the moderate group by $1 \%$ and in the mild group by 1\%. A $1 \%$ increase in $\mathrm{FEV}_{1} \%$ predicted decreased the odds of being in the severe group by $10 \%$, in the moderate group by $7 \%$ and in the mild group by $4 \%$. If the patient was taking ICS, the odds of being in the severe group rather than the normal group increased by a factor of 3.1 , in the moderate group by a factor of 2.1 and in the mild group by a factor of 1.5. This is likely an indication that more hyper-responsive patients were more likely to be taking ICS. LABA did not prove to be statistically significant nor did proximity to industry.

\section{DISCUSSION}

The results suggest that AHR is impacted by traffic from major roads in the Hamilton CMA. The critical distance at which patients were most likely to experience moderate AHR was within $200 \mathrm{~m}$ of major roads. The results also show that severe cases were most common in the urban core of the city where air pollution from anthropogenic sources, including traffic, is highest. The present study was the first to examine the relationship between airway responsiveness and major roadway proximity in adults in a Canadian urban environment using geographical spatial analysis. Unlike other studies that rely on patient's perception of symptoms or reports of physician-diagnosed asthma, the present study used an objective measurement of airway responsiveness.

One of the important aspects of the current study is that the subjects were primarily adults. While the literature is rich in studies relating to the impact of traffic on children, studies involving adults are less common. The database used in the present study was created from patients who attended a tertiary respiratory clinic. Therefore, it can be assumed that a significant number of patients in this population may have a pre-existing respiratory illness. Previous studies investigating the respiratory effects of traffic pollution have concluded that those with established respiratory conditions are more susceptible to health risks associated with traffic pollutants (18). A recent study by Künzli et al (20) demonstrated a relationship between adult-onset asthma and traffic-related pollution changes over 11 years in a Swiss cohort of 2725 never smokers. Balmes et al (19) identified a positive relationship between $\mathrm{FEV}_{1} \%$ predicted and distance from nearest roadway in a California study. There have been few studies in Canada. Lwebuga-Mukasa et al (3) identified an association between residential proximity to the Peace Bridge at the United States-Canadian border at Fort Erie, Ontario, traffic volume and hospital discharge rates for asthma. 
Other studies have demonstrated that living in an urban environment is a risk factor for respiratory illness including AHR (29). Schikowski et al (17) demonstrated an increased risk of chronic obstructive pulmonary disease and reduced lung function in women living within $100 \mathrm{~m}$ of a busy German road. Similarly, Venn et al (9) determined that $90 \mathrm{~m}$ from a main road was the critical distance at which children were at increased risk of wheezing illness. While most studies focus on distances $50 \mathrm{~m}$ to $150 \mathrm{~m}$ from roads (30-33), we found no significant association with $\mathrm{PC}_{20}$ at distances less than $175 \mathrm{~m}$ in unadjusted analyses, and $200 \mathrm{~m}$ in adjusted analyses. We note, however, that the results indicate nonsignificant but increased odds of having moderate AHR for people living closer than $200 \mathrm{~m}$ as shown in Figure 2. It is possible that the small number of patients in the buffer zones closer to the major roadways had an impact on the analyses. In the closest $50 \mathrm{~m}$ to major roads, for example, there were 47 patients with moderate AHR. However, significance at the $90 \%$ confidence level is worth noting. A study by Pujades-Rodriguez et al (34) studied the effect of living close to a main road on asthma, allergy, lung function and chronic obstructive pulmonary disease. This study concluded that living within $150 \mathrm{~m}$ from a major road was not significantly associated with an increased risk of any of the outcome variables in any age group, with little evidence that risk increased with increasing proximity across the $0 \mathrm{~m}$ to $150 \mathrm{~m}$ range, where contrasts in traffic-related pollutant concentrations are greatest. This result is similar to ours, although we obtained a statistically significant association for AHR at $200 \mathrm{~m}$ from major roads.

There are plausible reasons for the wide zone of influence from major roads. Figure 1 shows that many of the dissemination areas in which patients resided are interior zones - that is, they do not have a boundary along a major road. A visual examination of the point locations of the homes (not shown for reasons regarding patient privacy) reveal that some of the severe and moderate cases who are some distance away from major roads or highways, are very close to railway lines. For example, within $100 \mathrm{~m}$ of roads and highways, the percentage of severe, moderate, mild and normal cases were 4\%, 13\%, 20\% and $63 \%$, respectively, while the corresponding percentages for cases within $100 \mathrm{~m}$ of an active railway track are $5 \%, 16 \%, 23 \%$, and $56 \%$, respectively. Most of the rail in Hamilton is confined to the industrial sector, but some lines pass through or near residential areas. Traditional locomotives are substantially more polluting than road traffic and, hence, while these cases are not indicative of the effects of road traffic on $\mathrm{PC}_{20}$, they may be indicative of transportation emissions nonetheless. We were not able to perform similar multivariate analyses with railway lines because there are very few patients living within these buffer zones. For example, within $100 \mathrm{~m}$ of railway lines, there were just 15 patients with moderate AHR. The comparison, however, suggest that a larger study focused on railway lines, and perhaps in multiple cities, might prove useful.

In other locations, there were a few small clusters of severe and moderate cases near large shopping areas and some schools. The affected homes in these cases are not on the major roads but may be behind a shopping mall, for example, which is closer to the main road. These are all potentially high-traffic areas and the results may reflect the impact of traffic, but not traffic from major roads. We also noted a cluster of severe and moderate cases in an area where two highways intersect and which is known to be heavily congested at peak hours. This suggests that proximity to highways needs to be weighted according to traffic congestion because this increases pollution significantly. Surprisingly, living within $500 \mathrm{~m}$ of the industrial zone did not prove to be a significant factor in any analyses. The proportion of cases within that buffer zone (severe $3.7 \%$, moderate $13.3 \%$, mild $20.2 \%$, normal $62.8 \%$ ) was similar to that outside the buffer (severe $4.4 \%$, moderate $10.5 \%$, mild $21.5 \%$, normal $63.6 \%$ ), although there appeared to be appreciably more moderate cases inside the industry buffer zone.

There may be several reasons why our results show that proximity to high-traffic roadways is associated with an increased - but not severe - risk of moderate AHR. It is likely that severe AHR is associated with other risk factors such as a genetic predisposition (35), exposure to other allergens on the test date (36) or acute viral infection (37). Furthermore, there are several limitations to the present study. First, we did not adjust for smoking history because this was not available in the master patient database. A comparable study by Finkelstein et al (38) also did not include smoking as a confounder or effect modifier. They argued, citing a study by Dockery et al (39), that the lung damage caused by smoking was reflected in lung function of the patient, and that measures of lung function, such as $\mathrm{FEV}_{1} \%$ predicted, would control for much of the effects of smoking. We also did not adjust for socioeconomic factors or occupational factors such as type of employment or time spent in traffic during a daily commute. The association between the use of ICS and severe AHR was not unexpected. It is likely to be confounded by severity rather than a causal association.

Improved results may have been obtained if actual traffic volumes were used, and a weighting factor included for areas where traffic congestion occurs frequently. Congested traffic emits much higher levels of pollution than free-flow traffic, and also prolongs exposure in one location because of the stand-still or slow-moving traffic in that location. Traffic volumes in confined areas, such as shopping districts, should also be a weighting factor in health impact analyses.

\section{CONCLUSIONS}

The results of the present study suggest that living in close proximity to major roadways and highways may be a risk factor for AHR in adults. We identified a statistically significant association between moderate AHR and living within $200 \mathrm{~m}$ of a roadway in an adult population of patients attending a respiratory clinic. This relationship was not statistically significant at distances $<200 \mathrm{~m}$ at the $95 \%$ confidence interval, but were at the $90 \%$ confidence interval. Despite not having a sufficient number of patients close to major highways for reliable analyses, there are indications that severe cases of AHR are associated with heavily trafficked highways, indicated by the clustering of severe cases near the intersection of two high-volume highways. Severe cases were also most common in the urban core of the city where air pollution from anthropogenic sources, including traffic, is highest. The present study used geographic spatial analysis to map residence proximity to major roadways and highways. It is unique because it focused on a Canadian urban environment using objective measurements of AHR in adults. Taken together with our previous observation that proximity to major roads contributes to a neutrophilic bronchitis (40), this is an important consideration of the morbidity in asthma.

FUNDING: Dr Nair is supported by a Canada Research Chair in Airway Inflammometry.

\section{REFERENCES}

1. Gauderman WJ, Vora H, McConnell R, et al. Effect of exposure to traffic on lung development from 10 to 18 years of age: A cohort study. Lancet 2007;369:571-7.

2. Beelen R, Hoek G, van den Brandt PA, et al. Long-term effects of traffic-related air pollution on mortality in a Dutch cohort (NLCS-AIR Study). Environ Health Perspect 2008;116:196-202.

3. Lwebuga-Mukasa JS, Oyana T, Thenappan A, et al. Association between traffic volume and health care use for asthma among residents at a US-Canadian border crossing point. J Asthma 2004:41:289-304.

4. Jerrett M, Finkelstein MM, Brook JR, et al. A cohort study of traffic-related air pollution and mortality in Toronto, Ontario, Canada. Environ Health Perspect 2009;117:772-7.

5. Hoek G, Brunekreef B, Goldbohm S, et al. Association between mortality and indicators of traffic-related air pollution in the Netherlands: A cohort study. Lancet 2002;360:1203-9.

6. Zhou Y, Levy JI. Factors influencing the spatial extent of mobile source air pollution impacts: A meta-analysis. BMC Pub Health 2007;7:89. 
7. Buonocore JJ, Lee HJ, Levy JI. The influence of traffic on air quality in an urban neighbourhood: A community-university partnership. Am J Pub Health 2009;99:S629-35.

8. Morgenstern V, Zutavern A, Cyrys J, et al. Atopic diseases, allergic sensitization, and exposure to traffic-related air pollution in children. Am J Respir Crit Care Med 2008;177:1331-7.

9. Venn AJ, Lewis SA, Cooper M, et al. Living near a main road and the risk of wheezing illness in children. Am J Respir Crit Care Med 2001;164:2177-80.

10. Hwang BF, Lee YL, Lin YC, et al. Traffic related air pollution as a determinant of asthma among Taiwanese school children. Thorax 2005;60:467-73.

11. Kim J, Smorodinsky S, Lipsett M, et al. Traffic-related air pollution near busy roads: The East Bay Children's Respiratory Health Study. Am J Respir Crit Care Med 2004;170:520-6.

12. Morgenstern V, Zutavern A, Cyrys Josef, et al. Atopic diseases, allergic sensitization, and exposure to traffic-related air pollution in children. Am J Respir Crit Care Med 2008;177:1331-7.

13. Garshick E, Laden F, Hart JE, et al. Residence near a major road and respiratory symptoms in U.S. veterans. Epidemiology 2003;14:728-36.

14. Cesaroni G, Badaloni C, Porta D, et al. Comparison between various indices of exposure to traffic-related air pollution and their impact on respiratory health in adults. Occup Environ Med 2008;65:683-90.

15. Oosterlee A, Drijver M, Lebret E, et al. Chronic respiratory symptoms in children and adults living along streets with high traffic density. Occup Environ Med 1996;53:241-7.

16. Suglia SF, Gryparis A, Schwartz J, et al. Association between traffic-related black carbon exposure and lung function among urban women. Environ Health Perspect 2008;116:1333-7.

17. Schikowski T, Sugiri D, Ranft U, et al. Long-term air pollution exposure and living close to busy roads are associated with COPD in women. Respir Res 2005;6:152-62.

18. McCreanor J, Cullinan P, Nieuwenhuijsen MJ, et al. Respiratory effects of exposure to diesel traffic in persons with asthma. N Engl J Med 2007;357:2348-58.

19. Balmes JR, Earnest G, Katz PP, et al. Exposure to traffic: Lung function and health status in adults with asthma. J Allergy Clin Immunol 2009;123:626-31.

20. Künzli N, Bridevaux P-O, Liu L-J S, et al, Traffic-related air pollution correlates with adult-onset asthma among never-smokers. Thorax 2009;64:664-70. doi:10.1136/thx.2008.110031.

21. Juniper EF, Cockcroft DW, Hargreave FE. Histamine and Methacholine Inhalation Tests: Tidal Breathing Method Laboratory Procedure and Standardisation, 2nd edn. Lund: AB Draco, 1994.

22. Cockcroft DW, Killian DN, Mellon JJ, et al. Bronchial reactivity to inhaled histamine: A method and clinical survey. Clin Allergy. 1977;7:235-43 <www.ene.gov.on.ca/en/publications/air/index.php> (Accessed October 2010).

23. American Thoracic Society: Guidelines for methacholine and exercise challenge testing. Am J Respir Crit Care Med $2000 ; 161309-29$.
24. American Thoracic Society. Standardization of spirometry, 1994 update. Am J Respir Crit Care Med 1995;152:1107-36.

25. Government of Ontario. Ontario Ministry of the Environment. Air Quality in Ontario 2008 Report. PIBS 7356e. 2010: Queen's Printer for Ontario.

26. Bayer-Oglesby L, Schindler C, Hazenkamp-von Arx ME, et al. Living near main streets and respiratory symptoms in adults: The Swiss Cohort Study on Air Pollution and Lung Diseases in Adults. Am J Epidemiol 2006;164:1190-8.

27. Zhu Y, Hinds WC, Kim S, Sioutas C. Concentration and size distribution of ultrafine particles near a major highway. J Air Wast Manage Assoc 2002;52:1032-42.

28. De Smith MJ, Goodchild MF, Longley PA. Geospatial Analysis: A Comprehensive Guide to Principles, Techniques and Software Tools. Leicester: Troubador Publishing Ltd, 2006.

29. Maio S, Baldacci S, Carrozzi L, et al. Urban residence is associated with bronchial hyperresponsiveness in Italian general population samples. Chest 2009;135:434-41.

30. McConnell R, Berhane K, Yao L, et al. Traffic, susceptibility, and childhood asthma. Environ Health Perspect 2006;114:766-72.

31. Morgenstern V, Zutavern A, Cyrys J, et al. Respiratory health and individual estimated exposure to traffic-related air pollutants in a cohort of young children. Occup Environ Med 2007;64:8-16.

32. Ryan PH, LeMasters G, Biagini J, et al. Is it traffic type, volume, or distance? Wheezing in infants living near truck and bus traffic. J Allergy Clin Immunol 2005;116:279-84.

33. van Vliet P, Knape M, de Hartog J, et al. Motor vehicle exhaust and chronic respiratory symptoms in children living near freeways. Environ Res 1997;74:122-32.

34. Pujades-Rodríguez M, Lewis S, Mckeever T, et al. Effect of living close to a main road on asthma, allergy, lung function and chronic obstructive pulmonary disease. Occup Environ Med 2009;66:679-684 doi:10.1136/oem.2008.043885.

35. Postma DS, Meyers DA, Jongepier H, et al. Genomewide screen for pulmonary function in 200 families ascertained for asthma. Am J Respir Crit Care Med 2005;172:446-52.

36. O'Byrne PM, Inman MD. Airway hyperresponsiveness. Chest 2003:123(3 Suppl):411S-6S.

37. Folkerts G, Busse WW, Nijkamp FP, et al. Virus-induced airway hyperresponsiveness and asthma. Am J Respir Crit Care Med 1998;157:1708-20.

38. Finkelstein MM, Jerrett M, DeLuca P, et al. Relation between income, air pollution and mortality: A cohort study. CMAJ 2003;169:397-402.

39. Dockery DW, Speizer FE, Ferris BG Jr, et al. Cumulative and reversible effects of lifetime smoking on simple tests of lung function in adults. Am Rev Respir Dis 1988;137:286-92.

40. Wallace J, D'silva L, Brannan J, Hargreave FE, Kanaroglou P, Nair P. Association between proximity to major roads and sputum cell counts. Can Respir J 2011;18:13-8. 


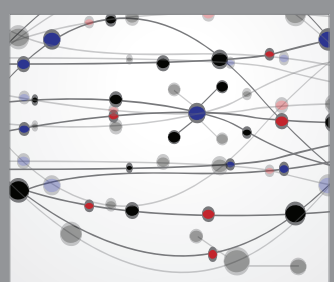

The Scientific World Journal
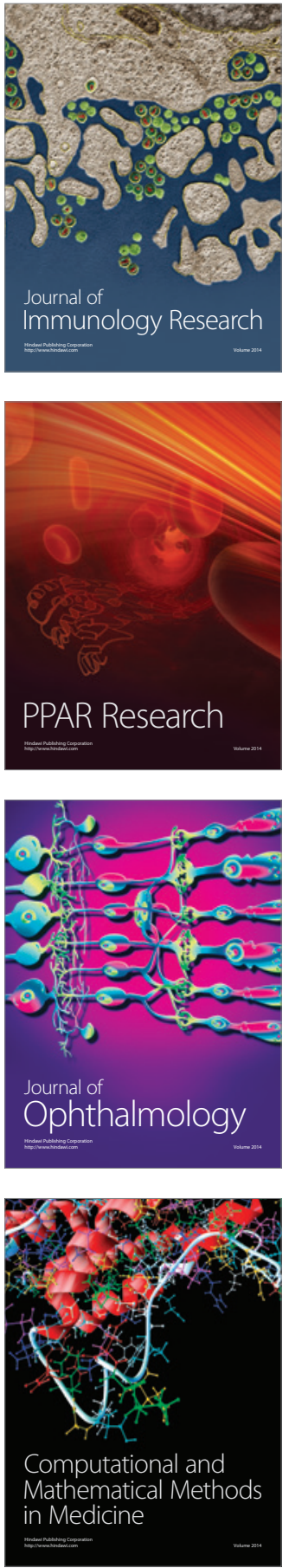

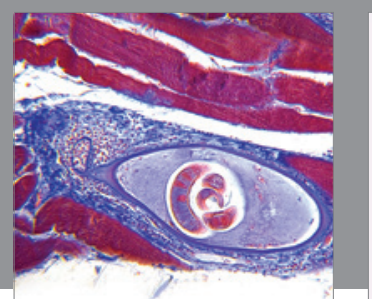

Gastroenterology Research and Practice

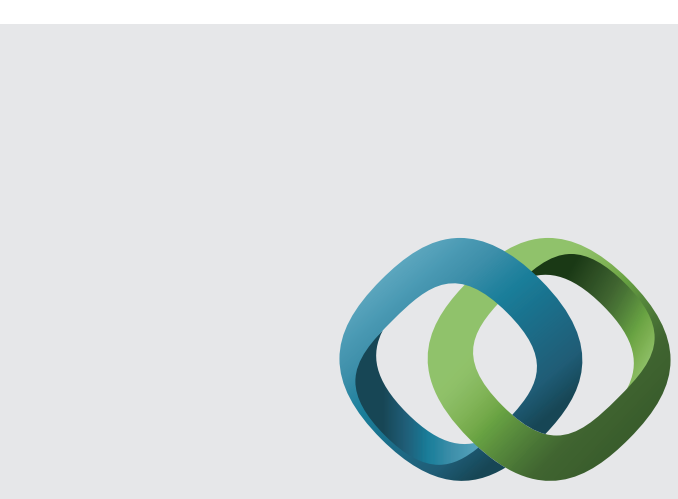

\section{Hindawi}

Submit your manuscripts at

http://www.hindawi.com
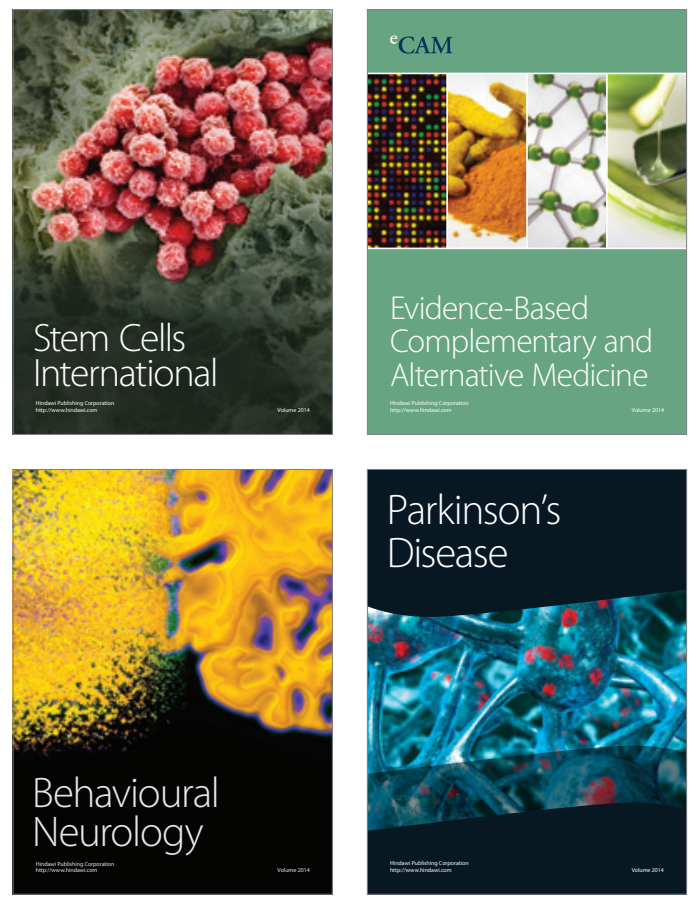
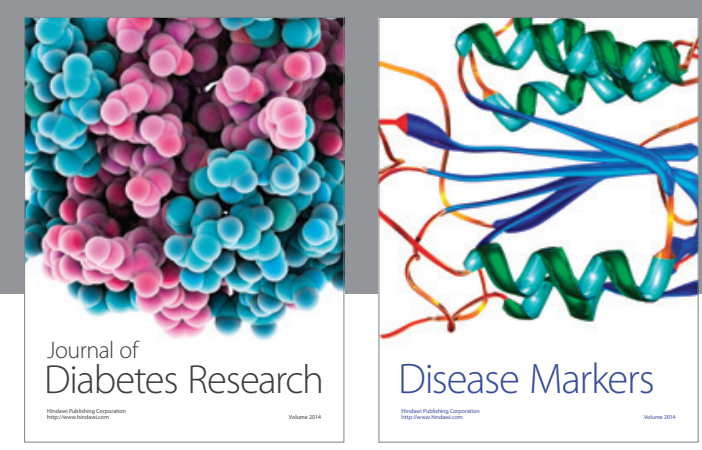

Disease Markers
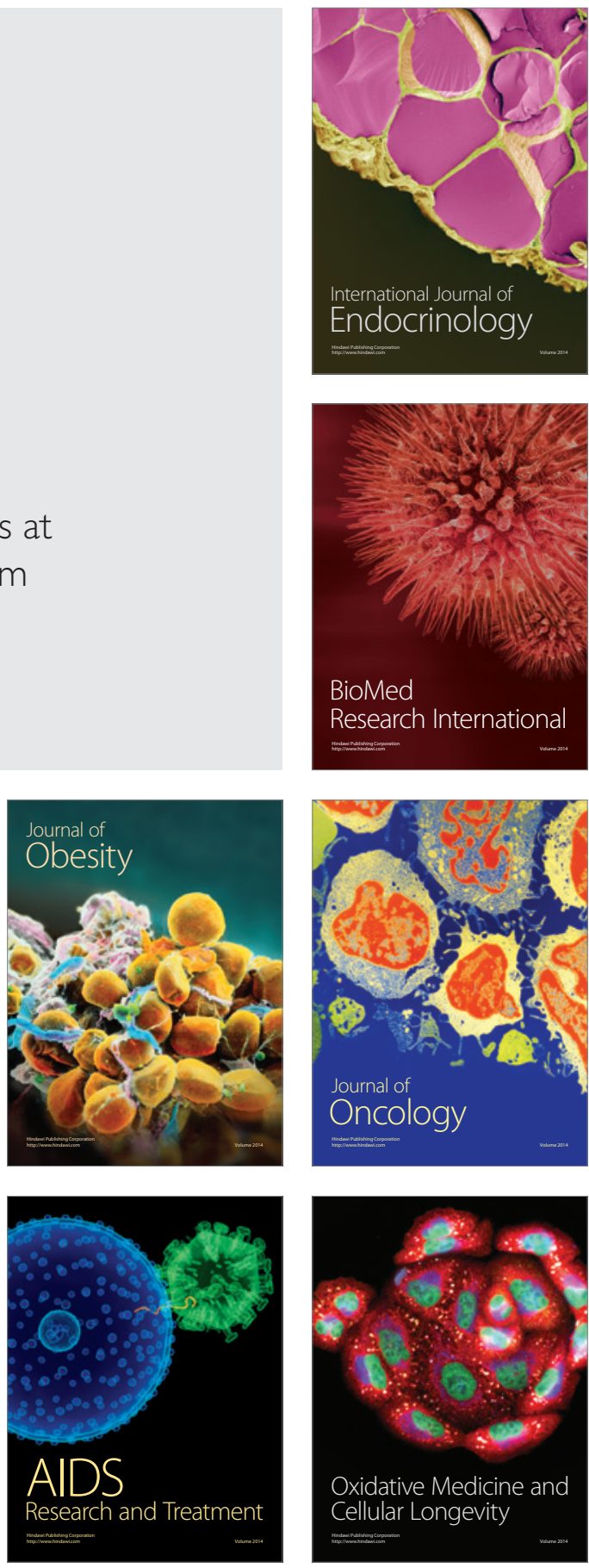